\title{
Correction to: 10-year follow-up of the Columbus knee prostheses system in a prospective multicenter study
}

\author{
Andreas Fuchs $^{1}$ (D) Philip Häussermann ${ }^{2} \cdot$ Dirk Hömig $^{3} \cdot$ Björn Gunnar Ochs ${ }^{4} \cdot$ Tim Klopfer $^{5} \cdot$ Christof A. Müller $^{6}$. \\ Peter Helwig $^{7} \cdot$ Lukas Konstantinidis $^{1}$
}

Published online: 5 October 2021

(c) The Author(s) 2021

\section{Correction to: Archives of Orthopaedic and Trauma Surgery https://doi.org/10.1007/s00402-021-04156-9}

The original version of this article unfortunately contained a mistake. Figure 2 was incorrect.

The corrected Fig. 2 is given in the following page.

Open Access This article is licensed under a Creative Commons Attribution 4.0 International License, which permits use, sharing, adaptation, distribution and reproduction in any medium or format, as long as you give appropriate credit to the original author(s) and the source, provide a link to the Creative Commons licence, and indicate if changes were made. The images or other third party material in this article are included in the article's Creative Commons licence, unless indicated otherwise in a credit line to the material. If material is not included in the article's Creative Commons licence and your intended use is not permitted by statutory regulation or exceeds the permitted use, you will need to obtain permission directly from the copyright holder. To view a copy of this licence, visit http://creativecommons.org/licenses/by/4.0/.

The original article can be found online at https://doi.org/10.1007/ s00402-021-04156-9.

Andreas Fuchs

andreas.fuchs@uniklinik-freiburg.de

1 Department of Orthopedics and Trauma Surgery, Faculty of Medicine, Medical Center, Albert-Ludwigs-University of Freiburg, Hugstetter Straße 55, 79016 Freiburg, Germany

2 Clinic for Orthopedics and Trauma Surgery, Sana Kliniken Leipziger Land, Borna, Germany

3 Clinic for Orthopaedic Surgery, Ortenau Klinikum, Offenburg, Gengenbach, Germany

4 Vincentius Orthopaedic Clinic, Konstanz, Germany

5 Clinic for Trauma Surgery, BG-Klinik Tübingen, Tübingen, Germany

6 Clinic for Trauma, Hand and Orthopaedic Surgery, Städtisches Klinikum Karlsruhe gGmbH, Karlsruhe, Germany

7 Clinic for Orthopedics and Trauma Surgery, Klinikum Heidenheim, Heidenheim, Germany
Publisher's Note Springer Nature remains neutral with regard to jurisdictional claims in published maps and institutional affiliations. 
210 patients included preoperatively

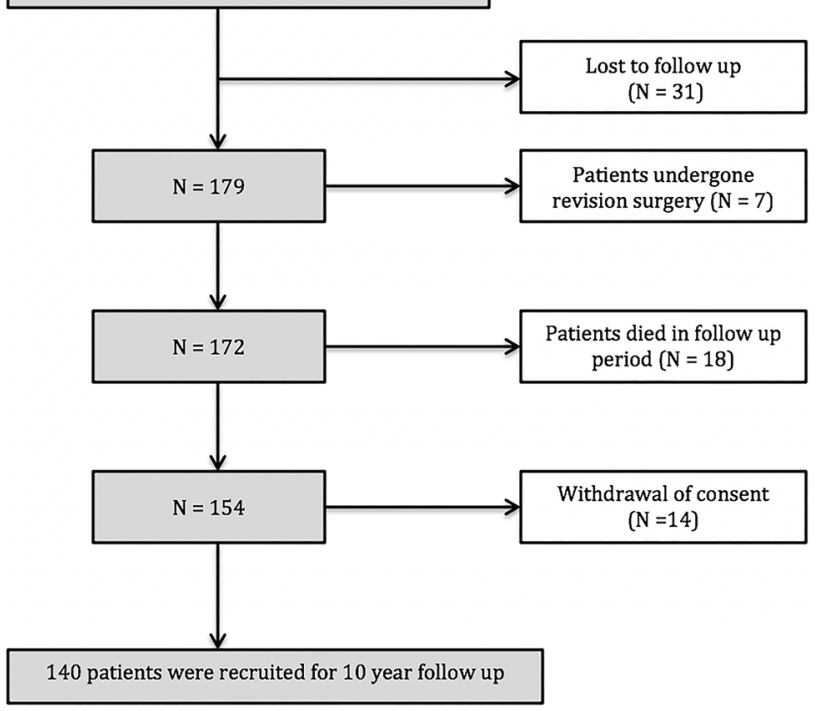

Fig. 2 Flowchart of study population with reason for study termination 